\section{Rocky Mountain}

The 1984 RMS Council Meeting was held on March 23 and 24, 1984 at the Edmonton Inn. The technical session was attended by approximately 100 people. The theme of the Annual Meeting was "AAC-Yield Regulation and Harvest Scheduling - What does it all mean?"

Speakers included:

1. Fred McDougall

Deputy Minister -

Renewable Resources

Topic: Why do we regulate yield?

2. Don Fregren

Director - Timber Management Branch, AFS

Topic: Provincial Prospective

3. Murray Summers

Woodlands Manager - Blue Ridge Lumber Ltd.

Topic: An Industrial Viewpoint

4. Jim Beck

Professor of Forest Management

Department of Forest Science, $U$ of $A$

Topic: Policies Affecting AAC

5. Richard Dempster

W.R. Dempster and Associates

Topic: The Problem of Yield Protection

6. Dean Marshall

Woodlands Manager

Spray Lakes Sawmills Ltd.

Topic: Quota Policy: A Smaller

Operator's Perspective

The Annual Meeting banquet was combined with the $U$ of $A$ graduation banquet and ring ceremony. The guest speaker for the banquet was Mr. Bill Moore, Vancouver Island logging contractor and freelance writer to the BC Lumberman magazine.

The RMS/CIF welcomed and presented rings to the $1984 \mathrm{U}$ of A Forestry graduating class of 25 individuals. Representing the CIF were Jim Clark, first vice-president and Lorne Brace, Chairman of the Rocky Mountain Section. Master of Ceremonies for the banquet was Brian MacDonald of Procter and Gamble Cellulose Ltd., Grande Prairie, Alberta.

The banquet and dance was a tremendous success and thoroughly enjoyed by the new graduates, their families, friends and ClFers. Many thanks to Evelyn Wrangler of the Alberta Forest Service who headed the organizing committee for the Annual Meeting, and to Kelly Lock, the 1984 class president, who led the committee organizing the banquet.

\section{4-85 RMS Council}

Director:

Chairman:

Vice-Chairman:

Counsellors:

Lorne Brace Howard Pratley

Randy Olson

Sharon Robertson

John Powell

Ross Waldron

Garry Leithead

Max Matthews

Ross Risvold

Brian Muhly

Secretary-Treasurer: Glen Armstrong

Howard G. Pratley

\title{
Upcoming Meetings
}

\section{Western International Forest Disease Work Conference}

The 32nd meeting of the Western International Forest Disease Work Conference will be held at Taos, New Mexico, from September 24-28. Anyone interested in attending should get in touch with:

Robert E. Wood

c/o Supervisor's Office

Lincoln National Forest

Federal Building

11 th and New York

Alamogordo, NM, 88310

or

Jerry S. Beatty

Southwestern Region

Forest Pest Management

517 Gold Avenue, S.W.

Albuquerque, NM, 87102

\section{Woodlands Equipment Field Demonstration}

\section{September 18-19-20, 1984 \\ Thunder Bay, Ontario, Canada}

Companies will be conducting active demonstrations of mobile equipment. Demonstrations will include all phases of harvesting and silviculture by the most upto-date equipment on the market. Suppliers of non-mobile equipment will have static displays of their products on the same site.

The demonstrations will take place on typical Northern Ontario woodlands terrain. The stands to be cut are a mixture of spruce, balsam, jackpine, poplar and birch.

\section{Hotel reservations:}

Barbara J. Fraser

Senior Info Officer

City of Thunder Bay

Public Affairs - Visitors \&

Convention Department

Paterson Park, 520 Leith Street

Thunder Bay, Ontario P7C $1 \mathrm{M} 9$

(807) 623-2711

\section{Further information:}

Tony A. Rotherham

Assistant Manager

CPPA - Woodlands Section

Sun Life Building

Suite 230

1155 Metcalfe Street

Montreal, Quebec H3B 2X9

(514) 866-6621
Western Forest Genetics Association

1984 Annual

Meeting

August 7 to 9, 1984

University of Victoria

Victoria, BC, Canada

Theme

Genetic Gain:

Incorporation and Implications for Forestry

\section{Purpose}

To provide a forum for those in tree improvement and forestry reviewing the potential and impact of tree improvement on forestry by the year 2050 .

\section{Program}

Panels, papers, poster sessions and field tours are being planned to explore the topic by both expert and generalist.

\section{Venue}

Victoria is British Columbia's most beautiful city and the University's setting and facilities are worthy of the city's reputation. Victoria is close to intensively managed private and public forest lands as well as "high tech" seed orchards of the Industry/Government Cooperative. Both will be part of the meeting's program.

\section{Plan Now to Attend}

Details regarding programs and registration will follow in early Spring.

Interested parties who are not on the mailing list and who wish to receive further information should submit their names to: Mr. Tom Lietaer, Conference Officer, University Extension Conference Office, University of Victoria, P.O. Box 1700 , Victoria, B.C. V8W $2 Y 2$ 